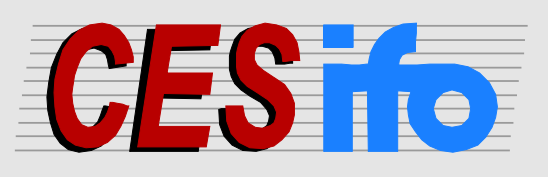

\title{
Working
}

Papers

www.cesifo.org/wp

\section{Government Ideology and Tuition Fee Policy: Evidence from the German States}

\author{
Björn Kauder \\ Niklas Potrafke
}

CESIFO WORKING PAPER NO. 4205

CATEGORY 5: ECONOMICS OF EDUCATION

APRIL 2013

An electronic version of the paper may be downloaded

- from the SSRN website:

- from the RePEc website:

- from the CESifo website:

wWw.SSRN.com

Www.RePEc.org

www.CESifo-group.org/wp

\section{CESifo}




\title{
Government Ideology and Tuition Fee Policy: Evidence from the German States
}

\begin{abstract}
In January 2005 the German Supreme Court permitted the state governments to charge tuition fees. By exploiting the natural experiment, we examine how government ideology influenced the introduction of tuition fees. The results show that rightwing governments were active in introducing tuition fees. By contrast, leftwing governments strictly denied tuition fees. This pattern shows clear political alternatives in education policy across the German states: the political left classifies tuition fees as socially unjust; the political right believes that tuition fees are incentive compatible. By the end of 2014, however, there will be no tuition fees anymore: the political left won four state elections and abolished tuition fees. In Bavaria the rightwing government also decided to abolish tuition fees because it feared to become elected out of office by adhering to tuition fees. Electoral motives thus explain convergence in tuition fee policy.
\end{abstract}

JEL-Code: D720, I220, I280, H750.

Keywords: tuition fees, education policy, government ideology, partisan politics.

Björn Kauder

Ifo Institute - Leibniz-Institute

for Economic Research

at the University of Munich

Poschingerstraße 5

Germany - 81679 Munich

kauder@ifo.de
Niklas Potrafke

Ifo Institute - Leibniz-Institute

for Economic Research

at the University of Munich

Poschingerstraße 5

Germany-81679 Munich

potrafke@ifo.de

10 April 2013

We received helpful comments from Marius Busemeyer, Nadja Dwenger, Julian Garritzmann, Radhika Lahiri, Mariana Lopes da Fonseca, Panu Poutvaara, Dirk Schindler, Alessandro Tampieri, Markus Tepe, and at the Australasian Public Choice Conference 2012, the Public Choice Society Meeting 2013 and the European Public Choice Society Meeting 2013. 


\section{Introduction}

Government ideology is likely to influence education policy. Conventional wisdom has been that leftwing governments spend more on education than rightwing governments. The partisan theories predict that political parties gratify the needs of their constituencies. Leftwing parties have received a great deal of electoral support by the working class and low-income voters. Because the working class and low-income voters may not afford to finance private education or to pay tuition fees, leftwing governments are expected to publicly finance education. Electoral cohesion has however declined and party positions have moved. Leftwing governments do no longer represent the working class but rather the middle class. It is conceivable that politicians gratify their constituencies by spending money on higher and lower education. We elaborate on theoretical predictions and empirical findings in Section 2.

The introduction of tuition fees in Germany in 2006 is an especially worthwhile objective to investigate ideology-induced education policies because of two reasons. ${ }^{3}$ First, tuition fees were not allowed in Germany for a long time. In January 2005, the German Supreme Court permitted the state governments to introduce tuition fees. Second, government ideology did not play an important role in economic policy-making at the federal level (e.g. De Haan and Zelhorst 1993, Berger and Woitek 1997, Potrafke 2012). Policies of the rightwing Christian Democrats and the leftwing Social Democrats have converged. Germany is however a federal state with 16 individual states (Laender). It is conceivable that government ideology influences economic policy-making at the state level. The German Laender governments have hardly any means to raise taxes and are also restrained in many policy fields. The Laender governments are however responsible for education policies. An intriguing question therefore is whether ideological differences are transpired by education policies in the German Laender. Previous research has indeed shown that government

\footnotetext{
${ }^{3}$ Scholars have investigated how the adaption of tuition fees in Germany has influenced mobility of university applicants (Dwenger et al. 2012, Alecke and Mitze 2012) and students' enrollment decisions (Hübner 2012, Dietrich and Gerner 2012).
} 
ideology influences public spending for universities and schooling (Oberndorfer and Steiner 2007, Wolf 2007, Potrafke 2011a). ${ }^{4}$ Introducing tuition fees has been controversial across the German states. By exploiting the natural experiment, we examine how government ideology influenced the introduction of tuition fees. ${ }^{5}$

\section{Government ideology and education policy}

Leftwing governments are expected to spend more on education than rightwing governments. The significant difference between leftwing and rightwing governments in the education system is that leftwing governments favor the expansion of public authority in the education system, whereas rightwing governments favor private alternatives (Busemeyer 2009). In Switzerland, for example, social democratic ideology has had a negative influence on privatizing education (Merzyn and Ursprung 2005). Scholars have investigated the influence of government ideology on total education spending and often find that overall education spending was higher under leftwing governments in OECD countries (Boix 1997, Schmidt 2007, Busemeyer 2007 and 2009, Ansell 2008, Potrafke 2011b). By contrast, the results by Jensen (2011) do not suggest that overall education spending was higher under leftwing governments in the period 1980-2000 in OECD countries. Jensen's (2011) argument confronts with the "Boix model" predicting that total education spending is higher under social democratic governments: leftwing governments will not increase total education expenditure but rather decrease it because redistribution - the leftist ultimate goal - can be optimized by other policy areas such as social policy.

\footnotetext{
${ }^{4}$ Rightwing governments in the German states have also been shown to increase police employment (Tepe and Vanhuysse 2013).

${ }^{5}$ See Kemnitz $(2007,2010)$ on how tuition fees influence the quality of higher education and Schindler (2011) on how tuition fees influence the labor tax schedule. Poutvaara and Kanniainen (2000) study a social contract on financing higher education between high-ability and low-ability agents, implemented using tax schedules. Poutvaara (2011) studies how subsidies to higher education and income tax schedule interact in the political process.
} 
Politicians spend money on lower and higher education. An extension of the Boix model predicts that leftwing governments increase spending on primary and secondary education and decrease spending on tertiary education. The traditional clientele of leftwing parties such as workers profit more from spending on primary and secondary education than on tertiary education. ${ }^{6}$ In the German Laender, for example, leftwing governments have somewhat increased spending for schooling, whereas rightwing governments have increased spending for universities (Oberndorfer and Steiner 2007, Potrafke 2011a). ${ }^{7}$ Also total education expenditures have been shown to be lower under leftwing governments (Wolf 2007).

The share of students with a parental background traditionally associated with the clientele of the Social Democrats is still rather small. Consequently, the clientele of the Social Democrats will benefit more from public expenditures on lower education such as schooling. The model by Ansell (2008) also shows that rightwing parties are often proponents of increased spending on universities. ${ }^{8}$ In the Canadian provinces, leftwing parties have been associated with lower tuition fees than rightwing parties (Neill 2009). ${ }^{9}$ In Scotland, however, the Labour party supported tuition fees, while the other parties preferred to abolish tuition fees (Hassan and Warhurst 2001). In the British House of Commons, rightwing members of the Labour party were less likely to vote against the Labour's own proposal to introduce tuition fees than other Labour politicians (Benedetto and Hix 2007). In Hungary, both members of parliament and voters of the leftwing MSZP party have been more in favor of tuition fees than members of parliament and voters of the rightwing Fidesz-MPP party (Todosijevic 2005).

\footnotetext{
${ }^{6}$ Consumption values of higher education may also differ across individuals (Alstadsæter 2011).

${ }^{7}$ Schulze's (2008) results suggest that conservative politicians tend to spend more on research in relative terms. The results by Tepe and Vanhuysse (2009) show that incumbents accelerated hiring of new teachers before elections in the German Laender. In a similar vein, public employment increased before elections in Finland and Sweden (Dahlberg and Mörk 2011).

${ }^{8}$ To be sure, the model by Ansell (2008) views partisan choices on higher education "in a trilemma between the level of enrollment, the degree of subsidization, and the overall public cost of higher education" (p. 190). On ideology-induced education policy see also Iversen and Stephens (2008).

${ }^{9}$ Fisher et al. (2009) discuss the political economy of post-secondary education in three Canadian provinces.
} 
In the course of declining electoral cohesion, however, leftwing parties may want to cater for middle-class voter groups without alienating their core constituencies. Busemeyer (2009) therefore calls the extended Boix model into question and predicts higher spending for tertiary education under leftwing governments: "the reason why social democrats prefer public higher education institutions is that in this case the decision on the expansion of access to higher education is not delegated to private institutions, but remains within the reach of public authority" (Busemeyer 2009: 111f.). ${ }^{10}$ In a similar vein, Busemeyer et al. (2011) employ survey data conducted in Switzerland 2007 and find that proponents of the political left prefer high education expenditures (by the government and enterprises) and oppose individual tuition fees. How government ideology influences introducing tuition fees remains as an empirical question.

\section{Empirical analysis}

\subsection{The German political party landscape}

Two major political parties have characterized the political spectrum in Germany: the leftist Social Democratic Party (SPD) and the conservative Christian Democratic Union (CDU). In Bavaria, Germany's largest federal state by area, the conservatives are not represented by the CDU but by their sister party, the Christian Social Union (CSU). No party competition emerges between the CDU and the CSU and they form one fraction in the federal parliament (Bundestag). This is why we label both CDU in the empirical analysis. All federal chancellors and state prime ministers - except the green prime minister of Baden-Wuerttemberg elected in 2011 - were members of one of these two major blocs, SPD and CDU. We can therefore test for ideology-induced effects on this left-right dimension.

The much smaller Free Democratic Party (FDP) and the Greens (Bündnis 90/Die Grünen) have played an important role as coalition partners in the former West German

\footnotetext{
${ }^{10}$ Welsh (2004) analyzes the evolution of higher education in Germany.
} 
states, the Left Party (Die Linke) as coalition partner in the East German states. While the SPD has formed coalitions with all the other four parties, the CDU never formed a coalition with the Left Party on the federal or state level. The CDU has formed coalitions with the SPD and the FDP. In Hamburg, the CDU has formed a coalition with the Greens over the period 2008-2011. In the Saarland, the CDU has formed a three party coalition with the FDP and the Greens over the period 2009-2011.

\subsection{The states in Germany's federalism}

Germany's constitution (Art. 30 and Art. 70 I) states that as many responsibilities as possible should rest with the Laender. De facto, the federal government has by far the greatest authority (e.g., Blankart 2008: Chapter 28, Blankart 2007: Chapter 7).

The Laender governments can decide only upon few policy fields. In some policy fields such as civil or employment law, the Laender and the federal government share authority. By contrast, the Laender run and finance the education system. It is therefore all the more indicative that the federal government abolished tuition fees in 1970. In 2003, six Laender with rightwing governments went to the German Supreme Court to claim their authority for tuition fees. In January 2005, the German Supreme Court adjudicated upon the responsibilities: the Laender were enabled to charge tuition fees. ${ }^{11}$

Table 1 shows that most Laender introduced tuition fees of 500 Euro per term. Bavaria and North Rhine-Westphalia allowed their universities to charge less than 500 Euro. The government in Hamburg lowered the fee from 500 Euro to 375 Euro in 2008. In the Saarland the fee increased from 300 Euro to 500 Euro in the third term of study. Several states introduced exceptions e.g. for students with a specific family background or for high-potential

\footnotetext{
${ }^{11}$ For an analysis of the political discussion ahead of the Supreme Court decision see, for example, Krause (2008)
} 
students. Federal state banks and the public KfW bank offer student loans under non-market conditions. Student loans from private banks are also available. ${ }^{12}$

Table 1: Level of tuition fees in Germany

\begin{tabular}{lcc}
\hline & \multicolumn{2}{c}{ Fee per term (in Euro) } \\
\hline & Universities & $\begin{array}{c}\text { Universities of } \\
\text { Applied Sciences }\end{array}$ \\
\hline Baden-Wuerttemberg & 500 & 500 \\
Bavaria & $300-500$ & $100-500$ \\
Hamburg & $500 / 375^{*}$ & $500 / 375^{*}$ \\
Hesse & 500 & 500 \\
Lower Saxony & 500 & 500 \\
North Rhine-Westphalia & up to 500 & up to 500 \\
Saarland & $300 / 500^{* *}$ & $300 / 500^{* *}$
\end{tabular}

In the case of Bavaria and North Rhine-Westphalia the Universities can/could decide upon the tuition fees within the given interval

* Reduction to 375 Euro passed on $09 / 17 / 08$ and took effect as of the winter term $08 / 09$. ** Increase to 500 Euro in the third term of study.

\subsection{Anecdotal evidence}

Table 2 shows which state governments introduced tuition fees. ${ }^{13}$ In December 2005, two Laender with rightwing governments, Lower Saxony and Baden-Wuerttemberg, decided to introduce tuition fees. Other Laender with rightwing governments followed in 2006. Tuition fees were charged first in the winter term 2006/07 (in Lower Saxony and North RhineWestphalia), the summer term 2007 (in Baden-Wuerttemberg, Bavaria, and Hamburg), and the winter term 2007/08 (in the Saarland and Hesse). The left panel of Figure 1 shows that all West German Laender with rightwing governments, except Schleswig-Holstein, introduced tuition fees. Neither the West German Laender with leftwing governments, nor the East German Laender introduced tuition fees (see also Table 3). To be sure, rightwing governments in the East German states did not introduce tuition fees. Government ideology

\footnotetext{
${ }^{12}$ For a discussion of different tuition fee models see, for example, Ebcinoglu (2006). See Hoffmann (2011) for a discussion of tuition fees in Great Britain. Poutvaara (2004) analyzes graduate taxes and income-contingent loans in the context of mobile students.

${ }^{13}$ Until 1970 most universities charged "Hörergelder" of 150 DM as a predecessor of tuition fees.
} 
has been shown to not influence economic policy-making in the East German states. It is conceivable that parties did not have and could not build on established traditions in the former East German states (Potrafke 2013). Voters in the East German states have also experienced the socialist history. ${ }^{14}$ Because university access has been free in socialist societies, voters in the East German states may well favor free university access, their political party identification notwithstanding. Grand coalitions (CDU and SPD together in government) did not introduce tuition fees in the East and West German states.

The parliaments of Hesse and the Saarland again revoked tuition fees in 2008 and 2010. In Hesse, a leftwing majority in the parliament decided to abolish tuition fees as of the winter term 2008/09, although a rightwing (managing) prime minister was still in office. ${ }^{15}$ In the Saarland a coalition of CDU, FDP and the Greens abolished tuition fees as of the summer term 2010 as a concession to the Greens.

Table 2: Only rightwing governments introduced tuition fees

\begin{tabular}{|c|c|c|c|c|c|c|}
\hline & \multicolumn{3}{|c|}{ Introduction } & \multicolumn{3}{|c|}{ Abolition } \\
\hline & $\begin{array}{c}\text { Passage } \\
\text { of bill }\end{array}$ & $\begin{array}{l}\text { Taking } \\
\text { effect }\end{array}$ & $\begin{array}{c}\text { Govern- } \\
\text { ment }\end{array}$ & $\begin{array}{c}\text { Passage } \\
\text { of bill }\end{array}$ & $\begin{array}{l}\text { Taking } \\
\text { effect }\end{array}$ & $\begin{array}{c}\text { Govern- } \\
\text { ment }\end{array}$ \\
\hline Baden-Wuerttemberg & $12 / 15 / 05$ & st 07 & CDU/FDP & $12 / 21 / 11$ & st 12 & Greens/SPD \\
\hline Bavaria & $05 / 18 / 06$ & st 07 & $\mathrm{CSU}$ & & & \\
\hline Hamburg & $06 / 28 / 06$ & st 07 & $\mathrm{CDU}$ & $12 / 15 / 11$ & wt $12 / 13$ & SPD \\
\hline Hesse & $10 / 05 / 06$ & wt $07 / 08$ & $\mathrm{CDU}$ & $06 / 17 / 08$ & wt $08 / 09$ & $*$ \\
\hline Lower Saxony & $12 / 09 / 05$ & wt $06 / 07$ & CDU/FDP & & & \\
\hline North Rhine-Westphalia & 03/16/06 & wt $06 / 07$ & $\mathrm{CDU} / \mathrm{FDP}$ & $02 / 24 / 11$ & wt $11 / 12$ & SPD/Greens** \\
\hline Saarland & $07 / 12 / 06$ & wt $07 / 08$ & $\mathrm{CDU}$ & $02 / 10 / 10$ & st 10 & CDU/FDP/Greens \\
\hline
\end{tabular}

st=summer term, wt=winter term. * Majority of SPD, Greens, and Left Party, with (managing) CDU prime minister. ** Minority government tolerated by the Left Party.

\footnotetext{
${ }^{14}$ On the "shadows of socialist past" and preference differences between East Germans and West Germans see also Bauernschuster et al. (2012).

${ }^{15}$ Hesse did not have a regular government between January 2008 and February 2009 because the leftwing majority in the parliament failed to elect its prime minister candidate after the 2008 state election. Because the leftwing majority abolished tuition fees, we consider the situation in the following as a leftwing government.
} 
Figure 1: Tuition fees and government ideology in the German states: winter term 2007/2008 and winter term 2012/2013
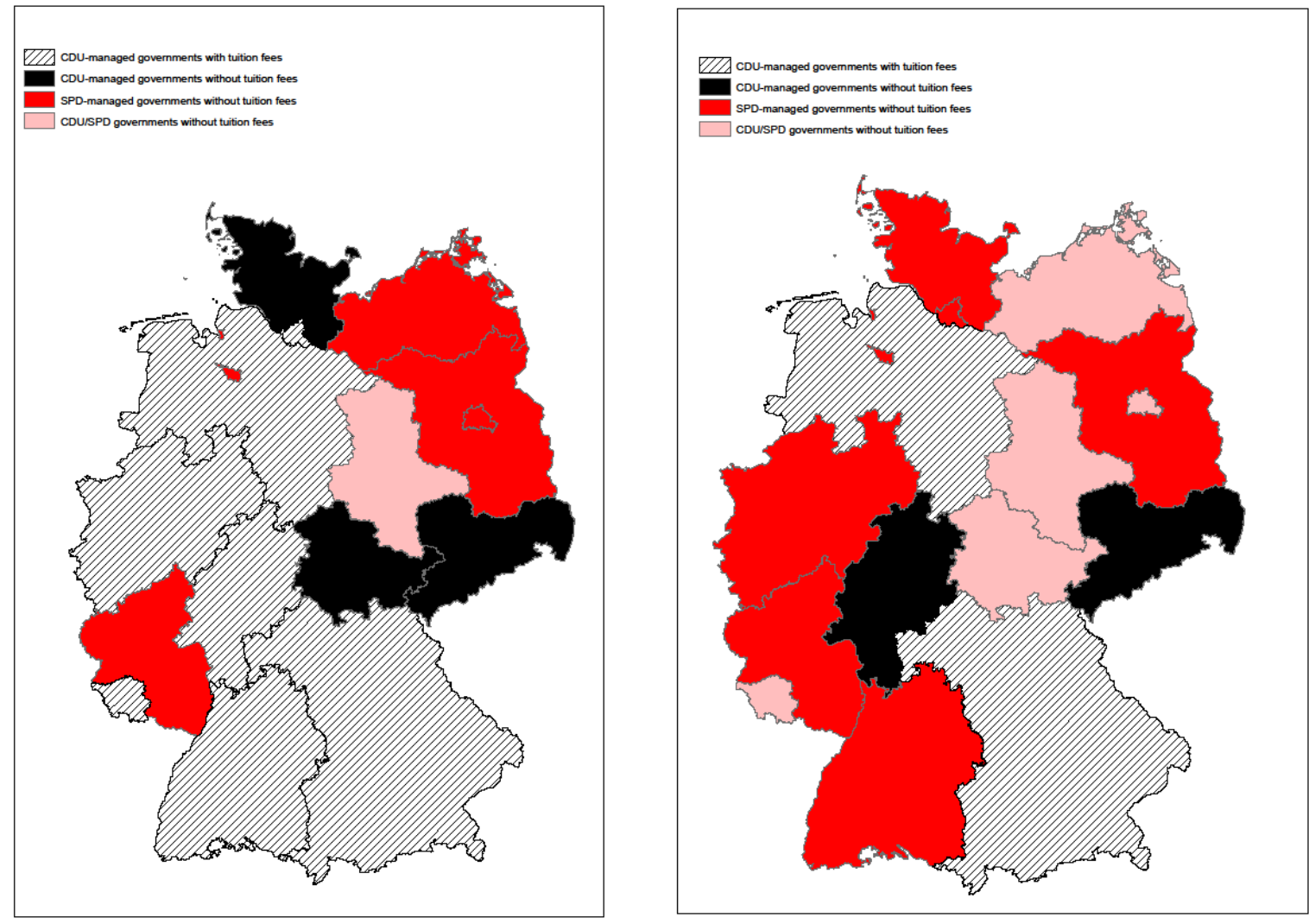

Table 3: Laender without tuition-fee history

\begin{tabular}{lccc}
\hline & \multicolumn{3}{c}{ Governments since 2005 } \\
\hline Berlin & SPD/Left Party & SPD/CDU & \\
Brandenburg & SPD/CDU & SPD/Left Party & \\
Bremen & SPD/CDU & SPD/Greens & \\
Mecklenburg-Western Pomerania & SPD/Left Party & SPD/CDU & \\
Rhineland-Palatinate & SPD/FDP & SPD & SPD/Greens \\
Saxony & CDU/SPD & CDU/FDP & \\
Saxony-Anhalt & CDU/FDP & CDU/SPD & \\
Schleswig-Holstein & SPD/Greens & CDU/SPD & CDU/FDP \\
Thuringia & CDU & CDU/SPD & \\
\hline
\end{tabular}

Coalitions with multiple legislative periods in a state are displayed only once. 
To identify ideology-induced effects in our panel data model including fixed state effects (see the next sections), we exploit identifying variation from changes in governments within the states. Over our sample period, there have been three changes between pure rightwing and pure leftwing governments and one change from a CDU/Greens government to an SPD government. In Schleswig-Holstein, the rightwing government has been replaced by a leftwing government in 2012. The rightwing government did however not implement tuition fees, nor did the newly elected leftwing government. By contrast, in North Rhine-Westphalia, Baden-Wuerttemberg, and Hamburg, the CDU/FDP and CDU/Greens governments have been elected out of office in 2010 and 2011. The newly elected leftwing governments immediately abolished tuition fees. The leftwing governments abolished tuition fees as of the winter term $2011 / 12$, the summer term 2012, and the winter term 2012/13. In the winter term $2012 / 13$ only the rightwing governments in Bavaria and Lower Saxony still charged tuition fees. We elaborate on policy changes after the winter term 2012/13 in the conclusion. The right panel of Figure 1 shows that all Laender with newly elected leftwing governments abolished tuition fees. Tuition fees are a prime example for ideology-induced policy-making in the German states.

\subsection{Empirical strategy}

We use data on the level of tuition fees collected from the various Laender laws. The dataset contains data for tuition fees and the government composition for the 16 German Laender on a term basis (two observations per year). The observation period runs from the summer term 2005 to the winter term 2012/13, which results in 16 observations per state. 
The basic panel data model has the following form:

Tuition fees $_{\mathrm{i}, \mathrm{t}}=\alpha$ Left $_{\mathrm{i}, \mathrm{t}-\mathrm{s}}+\beta$ Share of rightwing voters $\mathrm{i}_{\mathrm{i}, \mathrm{t}-\mathrm{s}}+\eta_{\mathrm{i}}+\varepsilon_{\mathrm{t}}+\mathrm{u}_{\mathrm{i}, \mathrm{t}}$

with $\mathrm{i}=1, \ldots, 16 ; \mathrm{t}=1, \ldots, 16 ; \mathrm{s}=1, \ldots, 3$

where the dependent variable Tuition fees ${ }_{i, t}$ describes the level of tuition fees (in Euro) in state $i$ at time $t .{ }^{16}$ Left $_{\mathrm{i}, \mathrm{t}-\mathrm{s}}$ describes the ideological orientation of the respective government $s$ terms ago. ${ }^{17}$ In the next paragraph we describe these variables and their coding in detail. Share of rightwing voters $\mathrm{i}_{\mathrm{i}, \mathrm{t}-\mathrm{s}}$ describes the share of rightwing voters (CDU/CSU and FDP) in state $i$ in period $t$-s. We use the vote shares of the last state elections. The vote shares therefore do not differ in the terms belonging to one legislative period. For robustness tests, we have alternatively used the share of leftwing voters (SPD, Greens, Left Party and SPD, Greens). We include the vote shares as an explanatory variable to disentangle the effect of government ideology and voter preferences on tuition fee policies (see, e.g. Elinder and Jordahl 2013, Freier and Odendahl 2012 and Liang 2013). $\eta_{i}$ describes a fixed state effect, $\varepsilon_{t}$ is a fixed time effect and $\mathrm{u}_{\mathrm{i}, \mathrm{t}}$ describes an error term.

We test the differences between leftwing and rightwing governments on the left-right scale using the variable "Left". The variable "Left" takes on the value of one in periods when the SPD was in office without a coalition partner, or formed a coalition with another leftwing party (Greens, Left Party, $\mathrm{SSW}^{18}$, or a combination) or the FDP. The variable Left takes on the value 0.5 for coalitions of the CDU with a leftwing party (grand coalitions with the SPD, coalitions with the Greens, or coalitions with both the Greens and the FDP). The variable Left is zero for CDU governments without a coalition partner, and for coalitions with the FDP.

\footnotetext{
${ }^{16}$ In the states of Bavaria, North Rhine-Westphalia, and the Saarland tuition fees may differ among terms or universities. We assume the commonly charged tuition fee of 500 Euro for these states.

${ }^{17} \mathrm{We}$ consider the government ideology at the beginning of the respective term.

${ }^{18}$ The SSW (Südschleswigscher Wählerverband) is the party of the Danish minority in Schleswig-Holstein.
} 
With respect to the grand coalitions, we do not distinguish which of the two parties appointed the Prime Minister. Since a time lag characterizes the implementation of tuition fee policies (section 3.3), we use the government variable with a lag of one, two, or three terms. We do not include all lags simultaneously because the lags are strongly correlated with each other and we would like to avoid multicollinearity problems.

Our regression model does not include other control variables because data on potential control variables are not yet available till the winter term 2012/13. We have tested whether the states' population densities influenced the level of tuition fees. When population density is low (for example, in the East German states and Schleswig-Holstein), state governments may not introduce tuition fees to avoid students' emigration to states which do not charge tuition fees. The population densities, however, hardly vary over time, so that the fixed state effects capture their potential influence. The strong anecdotal evidence indicates that our parsimonious econometric model identifies ideology-induced education policies. Table 4 shows descriptive statistics. We estimate the model by using OLS with standard errors robust to heteroskedasticity (Huber/White/sandwich standard errors - see Huber 1967, White 1980 and 1982, and Stock and Watson 2008).

As robustness checks we also estimate the model based on legislative periods and cabinets rather than based on university terms. We consider the influence of ideology on the level of tuition fees (in Euro) at the end of the respective legislative period or cabinet. ${ }^{19}$ While the beginning of a legislative period is defined by the day of the state election, the beginning of a cabinet is defined by the day of the election of the state prime minister by the parliament. Our dataset includes ten more cabinets than legislative periods because some legislative

\footnotetext{
${ }^{19}$ Regarding legislative periods or cabinets that have not ended by the end of 2012, we consider the current level of tuition fees. The results are not sensitive to excluding the current legislative periods or cabinets. As first legislative periods or cabinets we consider those legislative periods or cabinets that ended after 1 April 2005, which is the first day of a possible introduction of tuition fees. The results are not sensitive to including the legislative period/cabinet of Schleswig-Holstein that ended before 1 April 2005 but after the Supreme Court decision in January 2005. Decisions about tuition fees took always effect during the same legislative periods or cabinets in which the decisions were made. Only the introduction of tuition fees in Baden-Wuerttemberg took effect in the legislative period/cabinet after the legislative period/cabinet in which the decision was made, but the government ideology was the same in both legislative periods/cabinets.
} 
periods include two cabinets (due to the election of a new prime minister within a legislative period). Tables 4, 5 and 6 show descriptive statistics.

Table 4: Descriptive statistics (university terms)

\begin{tabular}{|c|c|c|c|c|c|}
\hline Variable & Obs. & Mean & Std. Dev. & Min & $\operatorname{Max}$ \\
\hline Tuition fees & 256 & 0.246 & 0.432 & 0 & 1 \\
\hline Tuition fees in Euro & 256 & 119.1 & 210.0 & 0 & 500 \\
\hline SPD & 256 & 0.055 & 0.228 & 0 & 1 \\
\hline CDU & 256 & 0.160 & 0.367 & 0 & 1 \\
\hline CDU/FDP & 256 & 0.273 & 0.447 & 0 & 1 \\
\hline CDU/Greens & 256 & 0.020 & 0.139 & 0 & 1 \\
\hline CDU/FDP/Greens & 256 & 0.020 & 0.139 & 0 & 1 \\
\hline $\mathrm{CDU} / \mathrm{SPD}$ & 256 & 0.262 & 0.440 & 0 & 1 \\
\hline SPD/FDP & 256 & 0.012 & 0.108 & 0 & 1 \\
\hline SPD/Greens & 256 & 0.094 & 0.292 & 0 & 1 \\
\hline SPD/Left Party & 256 & 0.094 & 0.292 & 0 & 1 \\
\hline SPD/Greens/Left Party & 256 & 0.008 & 0.088 & 0 & 1 \\
\hline SPD/Greens/SSW & 256 & 0.004 & 0.063 & 0 & 1 \\
\hline Left & 256 & 0.416 & 0.410 & 0 & 1 \\
\hline Share of rightwing voters (CDU/FDP) & 256 & 42.73 & 10.59 & 19.4 & 60.7 \\
\hline $\begin{array}{l}\text { Share of leftwing voters } \\
\text { (SPD/Greens/Left Party) }\end{array}$ & 256 & 46.69 & 9.609 & 27.3 & 66.7 \\
\hline $\begin{array}{l}\text { Share of leftwing voters } \\
\text { (SPD/Greens) }\end{array}$ & 256 & 36.75 & 11.20 & 14.5 & 61.1 \\
\hline
\end{tabular}


Table 5: Descriptive statistics (legislative periods)

\begin{tabular}{|c|c|c|c|c|c|}
\hline Variable & Obs. & Mean & Std. Dev. & Min & Max \\
\hline Tuition fees & 44 & 0.227 & 0.424 & 0 & 1 \\
\hline Tuition fees in Euro & 44 & 110.8 & 207.4 & 0 & 500 \\
\hline SPD & 44 & 0.045 & 0.211 & 0 & 1 \\
\hline CDU & 44 & 0.114 & 0.321 & 0 & 1 \\
\hline CDU/FDP & 44 & 0.227 & 0.424 & 0 & 1 \\
\hline CDU/Greens & 44 & 0.023 & 0.151 & 0 & 1 \\
\hline CDU/FDP/Greens & 44 & 0.023 & 0.151 & 0 & 1 \\
\hline $\mathrm{CDU} / \mathrm{SPD}$ & 44 & 0.250 & 0.438 & 0 & 1 \\
\hline SPD/FDP & 44 & 0.023 & 0.151 & 0 & 1 \\
\hline SPD/Greens & 44 & 0.159 & 0.370 & 0 & 1 \\
\hline SPD/Left Party & 44 & 0.091 & 0.291 & 0 & 1 \\
\hline SPD/Greens/Left Party & 44 & 0.023 & 0.151 & 0 & 1 \\
\hline SPD/Greens/SSW & 44 & 0.023 & 0.151 & 0 & 1 \\
\hline Left & 44 & 0.511 & 0.424 & 0 & 1 \\
\hline Share of rightwing voters (CDU/FDP) & 44 & 41.24 & 10.54 & 19.4 & 60.7 \\
\hline $\begin{array}{l}\text { Share of leftwing voters } \\
\text { (SPD/Greens/Left Party) }\end{array}$ & 44 & 48.42 & 9.459 & 27.3 & 66.7 \\
\hline $\begin{array}{l}\text { Share of leftwing voters } \\
\text { (SPD/Greens) }\end{array}$ & 44 & 39.02 & 11.26 & 14.5 & 61.1 \\
\hline
\end{tabular}


Table 6: Descriptive statistics (cabinet periods)

\begin{tabular}{llllll}
\hline Variable & Obs. & Mean & Std. Dev. & Min & Max \\
\hline Tuition fees & 54 & 0.259 & 0.442 & 0 & 1 \\
Tuition fees in Euro & 54 & 125.0 & 214.5 & 0 & 500 \\
SPD & 54 & 0.037 & 0.191 & 0 & 1 \\
CDU & 54 & 0.111 & 0.317 & 0 & 1 \\
CDU/FDP & 54 & 0.259 & 0.442 & 0 & 1 \\
CDU/Greens & 54 & 0.037 & 0.191 & 0 & 1 \\
CDU/FDP/Greens & 54 & 0.037 & 0.191 & 0 & 1 \\
CDU/SPD & 54 & 0.259 & 0.442 & 0 & 1 \\
SPD/FDP & 54 & 0.019 & 0.136 & 0 & 1 \\
SPD/Greens & 54 & 0.130 & 0.339 & 0 & 1 \\
SPD/Left Party & 54 & 0.074 & 0.264 & 0 & 1 \\
SPD/Greens/Left Party & 54 & 0.019 & 0.136 & 0 & 1 \\
SPD/Greens/SSW & 54 & 0.019 & 0.136 & 0 & 1 \\
Left & 54 & 0.463 & 0.410 & 0 & 1 \\
Share of rightwing voters (CDU/FDP) & 54 & 42.39 & 10.48 & 19.4 & 60.7 \\
Share of leftwing voters & 54 & 47.53 & 9.354 & 27.3 & 66.7 \\
(SPD/Greens/Left Party) & & & & & \\
Share of leftwing voters & 54 & 38.37 & 11.15 & 14.5 & 61.1 \\
(SPD/Greens) & & & & & \\
\hline
\end{tabular}

\subsection{Regression Results}

Table 7 shows that leftwing governments reduce tuition fees. Column (1) includes government ideology in term $\mathrm{t}-1$ and does not include fixed time effects. The estimate indicates that a pure leftwing government reduces tuition fees by about 146 Euro as compared to a pure rightwing government. The coefficient turns out to be statistically significant at the $5 \%$ level. Column (2) includes government ideology in term t-2. The estimate indicates that a pure leftwing government reduces tuition fees by about 180 Euro as compared to a pure rightwing government. The third column shows a reduction of 128 Euro when a leftwing government was in office in term t-3. The effects are again statistically significant at the 5\% level. We include fixed time effects in columns (4) to (6) and obtain similar results as in the 
first three columns. A leftwing government reduces tuition fees by 146 Euro, 161 Euro, or 91

Euro (statistically significant effects at the $5 \%$ or $1 \%$ level).

Table 7: Regression results (university terms).

Dependent variable: level of tuition fees in Euro. OLS with standard errors robust to heteroskedasticity (Huber/White/sandwich standard errors)
(1)
(2)
(3)
(4)

(5)

(6)

\begin{tabular}{|c|c|c|c|c|c|c|}
\hline \multirow[t]{2}{*}{$\overline{\text { Left (first lag) }}$} & $-146.0^{* *}$ & & & $-145.9^{* *}$ & & \\
\hline & $(63.81)$ & & & $(60.55)$ & & \\
\hline \multirow[t]{2}{*}{ Left (second lag) } & & $-179.9^{* *}$ & & & $-161.3^{* *}$ & \\
\hline & & $(81.81)$ & & & $(68.98)$ & \\
\hline \multirow[t]{2}{*}{ Left (third lag) } & & & $-128.1 * *$ & & & $-90.70 * * *$ \\
\hline & & & $(47.97)$ & & & (29.17) \\
\hline Fixed State Effects & Yes & Yes & Yes & Yes & Yes & Yes \\
\hline Fixed Time Effects & No & No & No & Yes & Yes & Yes \\
\hline Observations & 240 & 224 & 208 & 240 & 224 & 208 \\
\hline Number of $n$ & 16 & 16 & 16 & 16 & 16 & 16 \\
\hline R-squared (overall) & 0.235 & 0.292 & 0.301 & 0.309 & 0.330 & 0.241 \\
\hline
\end{tabular}

Robust standard errors in parentheses; ** significant at $5 \%$; *** significant at $1 \%$

Table 8 shows results including the share of rightwing voters. The share of rightwing voters variable does not turn out to be statistically significant. Including the share of rightwing voters variable somewhat reduces the coefficient estimate of the leftwing government variable but does not render the leftwing government variable to lack statistical significance (except column 6). We have also replaced the share of rightwing voters (CDU and FDP) by two alternative variables to measure the share of leftwing voters: SPD, Greens and Left Party, and SPD and Greens. We have distinguished between the vote shares of the SPD, Greens and Left Party, and SPD and Greens because the Left Party had much larger influence in the East German states, and in the West German states, the SPD and Greens represent the political left. The share of leftwing voters variable (SPD, Greens and Left Party) is statistically significant in some specifications and has a negative sign. Including the share of leftwing voters variable (SPD, Greens and Left Party) renders the government ideology 
variable to lack statistical significance in some specifications. By contrast, the share of leftwing voters variable (SPD and Greens) is statistically significant in some specifications and has a positive sign. Including the share of leftwing voters variable (SPD and Greens) renders the government ideology variable to be statistically significant at larger levels as compared to when the share of rightwing voters is included (Table 8). It is important to note however that the government ideology variable and the share of rightwing/leftwing vote share variable are strongly correlated. The absolute values of the correlation coefficients vary between 0.46 and 0.74 . Including the share of rightwing/leftwing voters is thus likely to induce multicollinearity issues.

Table 8: Regression results (university terms). Share of rightwing voters included Dependent variable: level of tuition fees in Euro. OLS with standard errors robust to heteroskedasticity (Huber/White/sandwich standard errors)

\begin{tabular}{|c|c|c|c|c|c|c|}
\hline & (1) & (2) & (3) & (4) & (5) & (6) \\
\hline \multirow[t]{2}{*}{$\overline{\text { Left (first lag) }}$} & $-143.0^{* *}$ & & & $-146.4^{* *}$ & & \\
\hline & $(66.53)$ & & & $(61.28)$ & & \\
\hline \multirow[t]{2}{*}{ Left (second lag) } & & $-160.4^{*}$ & & & $-150.1^{*}$ & \\
\hline & & $(85.39)$ & & & $(73.03)$ & \\
\hline \multirow[t]{2}{*}{ Left (third lag) } & & & $-74.41 *$ & & & -56.14 \\
\hline & & & $(41.91)$ & & & $(38.97)$ \\
\hline Share of rightwing voters & 0.354 & 2.366 & 7.009 & -0.067 & 1.622 & 4.901 \\
\hline (first/second/third lag) & (3.698) & $(3.674)$ & $(4.399)$ & (3.918) & $(4.017)$ & $(4.396)$ \\
\hline Fixed State Effects & Yes & Yes & Yes & Yes & Yes & Yes \\
\hline Fixed Time Effects & No & No & No & Yes & Yes & Yes \\
\hline Observations & 240 & 224 & 208 & 240 & 224 & 208 \\
\hline Number of $n$ & 16 & 16 & 16 & 16 & 16 & 16 \\
\hline R-squared (overall) & 0.243 & 0.325 & 0.354 & 0.308 & 0.364 & 0.359 \\
\hline
\end{tabular}

Robust standard errors in parentheses; * significant at 10\%; ** significant at $5 \%$

We have tested whether the results are sensitive to idiosyncratic circumstances in the individual states. For this reason, we tested whether the results are sensitive to the inclusion or exclusion of particular states. In the specifications without the vote share variable the results 
are not sensitive to the inclusion or exclusion of any individual state in more than $98 \%$ of the robustness regressions. In the specifications including the vote share variable, however, the inclusion or exclusion of individual states renders the leftwing government variable to lack statistical significance in many cases.

Table 9 shows the regression results on the basis of legislative periods rather than on the basis of university terms. The results confirm that leftwing governments reduce tuition fees. Column (1) shows that in a legislative period a pure leftwing government reduces tuition fees by about 262 Euro as compared to a pure rightwing government. The effect is statistically significant at the $1 \%$ level. We obtain a similar result of 255 Euro when we include fixed time effects in column (2). The effect is again statistically significant at the $1 \%$ level. The effects are somewhat smaller when we include the share of rightwing voters variable. The share of rightwing voters variable is statistically significant at the 5\% level when no fixed time effects are included (column 3). The share of rightwing voters variable does not turn out to be statistically significant when fixed time effects are included (column 4).

Table 9: Regression results (legislative periods).

Dependent variable: level of tuition fees in Euro. OLS with standard errors robust to heteroskedasticity (Huber/White/sandwich standard errors)

\begin{tabular}{lcccc}
\hline & $(1)$ & $(2)$ & $(3)$ & $(4)$ \\
\hline Left & $-262.1^{* * *}$ & $-254.8^{* * *}$ & $-181.4^{* * *}$ & $-217.8^{* * *}$ \\
Share of rightwing voters & $(72.75)$ & $(52.42)$ & $(62.46)$ & $(53.93)$ \\
& & & $8.702 * *$ & 6.124 \\
Fixed State Effects & Yes & Yes & $(3.527)$ & $(7.740)$ \\
Fixed Time Effects & No & Yes & No & Yes \\
\hline Observations & 44 & 44 & 44 & Yes \\
Number of n & 16 & 16 & 16 & 16 \\
R-squared (overall) & 0.371 & 0.416 & 0.438 & 0.454 \\
\hline
\end{tabular}

Robust standard errors in parentheses; $* *$ significant at $5 \%$; *** significant at $1 \%$ 
Table 10 shows the regression results on the basis of cabinet periods. Column (1) shows that when we consider cabinets as time unit, a pure leftwing government reduces tuition fees by about 243 Euro as compared to a pure rightwing government. The effect is statistically significant at the $1 \%$ level. We obtain a similar result of 233 Euro when we include fixed time effects in column (2). The effect is statistically significant at the $5 \%$ level. The numerical meaning of the government ideology variable in column (3) is that a pure leftwing government reduces tuition fees by about 160 Euro as compared to a pure rightwing government. In column (4) the government ideology variable fails statistical significance at conventional levels.

Table 10: Regression results (cabinet periods). Dependent variable: level of tuition fees in Euro. OLS with standard errors robust to heteroskedasticity (Huber/White/sandwich standard errors)

\begin{tabular}{lcccc}
\hline & $(1)$ & $(2)$ & $(3)$ & $(4)$ \\
\hline Left & $-243.3^{* * *}$ & $-233.4^{* *}$ & $-160.0^{* *}$ & -152.3 \\
Share of rightwing voters & $(72.05)$ & $(89.32)$ & $(64.19)$ & $(89.58)$ \\
& & & $8.995^{* *}$ & 11.67 \\
Fixed State Effects & & & $(3.763)$ & $(9.107)$ \\
Fixed Time Effects & Yes & Yes & Yes & Yes \\
\hline Observations & No & Yes & No & Yes \\
Number of n & 54 & 54 & 54 & 54 \\
R-squared (overall) & 16 & 16 & 16 & 16 \\
\hline
\end{tabular}

Robust standard errors in parentheses; $* *$ significant at $5 \%$; *** significant at $1 \%$

Government ideology also influences the introduction or abolition of tuition fees. We have estimated a panel probit model and find significant effects. 


\section{Conclusion}

The introduction of tuition fees in the German states has been a prime example for ideologyinduced education policies: rightwing governments were active in introducing tuition fees; leftwing governments strictly denied tuition fees. The result is revealing because ideology retired to the background in German policy-making over the last decades. Given that the room to maneuver of German state governments is limited, the ideology-induced introduction of tuition fees invigorates partisan politics and political polarization. ${ }^{20} \mathrm{We}$ have included data till the winter semester 2012/13. In January 2013, the rightwing government in Lower Saxony lost the state elections. The new leftwing government immediately decided to abolish tuition fees. During the election campaign, there was strong policy polarization between the rightwing and leftwing bloc: the CDU and FDP were in favor of tuition fees and the SPD and Greens were against tuition fees. This case study evidence indicates ideology-induced tuition fee policies and that the political parties have gratified their core constituencies by introducing/abolishing tuition fees.

Why is it that leftwing and rightwing governments have implemented different policies? We examine party platforms of the SPD, CDU, FDP, the Greens and the Left Party in the German states. The appendix includes the sources of party platforms. The wordings on which we based our assessments are available upon request.

Table 11 shows that the SPD, the Greens, and the Left Party deny tuition fees in all 16 Laender and indeed claim tuition fees to be socially unjust. By contrast, the political right believes that tuition fees are incentive compatible. ${ }^{21}$ The FDP has favored tuition fees in 14 Laender. In Schleswig-Holstein and Saxony-Anhalt the FDP denies tuition fees. The party platforms of the FDP in Schleswig-Holstein and Saxony-Anhalt do however not indicate that tuition fees are unjust. The CDU has denied tuition fees in nine Laender (in Hesse since 2008

\footnotetext{
${ }^{20}$ On modeling political polarization and competition see, for example, Ursprung (2003).

${ }^{21}$ Hillman (2009) portrays the nexus between social justice and political ideology.
} 
and in the Saarland since 2010). Only the party platforms of the CDU in Rhineland-Palatinate and Saxony indicate that tuition fees are unjust. The CDU disavowed introducing tuition fees in states such as the Saarland and Hesse and the election campaign 2012 in North RhineWestphalia.

Table 11: Number of party platforms against tuition fees and classifying tuition fees as socially unjust

\begin{tabular}{lcc}
\hline & Against tuition fees & Tuition fees are socially unjust \\
\hline SPD & 16 & 16 \\
Greens & 16 & 16 \\
Left Party & 16 & 16 \\
CDU & 9 & 2 \\
FDP & 2 & 0
\end{tabular}

The appendix includes the list of party platforms. Note: in Hesse, the CDU was in favor of tuition fees till 2008. In the Saarland, the CDU was in favor of tuition fees till 2010. Information compiled in summer 2012.

Because the German electorate has moved to the left in the course of the financial crisis, some CDU politicians were concerned to not get elected by supporting tuition fees. The development of receding from the support of tuition fees has strengthened since 2012. In February 2013, the rightwing government in Bavaria decided to abolish tuition fees, six years after the conservative CSU introduced tuition fees in Bavaria. There are state elections in Bavaria in September 2013, and the rightwing government feared to lose votes without abolishing tuition fees. By the end of 2014, there will be no tuition fees in Germany anymore.

Electoral motives seem to overshadow ideological purposes in education policy making (Downs 1957). 


\section{References}

Alecke, B. \& Mitze, T. (2012). Studiengebühren und das Wanderungsverhalten von Studienanfängern: Eine panel-ökonometrische Wirkungsanalyse. Perspektiven der Wirtschaftspolitik 13, 357-386.

Alstadsæter, A. (2011). Measuring the consumption value of higher education. CESifo Economic Studies 57, 458-479.

Ansell, B.W. (2008). University challenges explaining institutional change in higher education. World Politics 60, 189-230.

Bauernschuster, S., Falck, O., Gold, R. \& Heblich, S. (2012). The shadows of the socialist past: lack of self-reliance hinders entrepreneurship, European Journal of Political Economy 28, 485-497.

Benedetto, G. \& Hix, S. (2007). The rejected, the ejected, and the dejected: explaining government rebels in the 2001-2005 British House of Commons. Comparative Political Studies 40, 755-781.

Berger, H. \& Woitek, U. (1997). Searching for political business cycles in Germany. Public Choice 91, 179-197.

Blankart, C.B. (2007). Föderalismus in Deutschland und Europa. Baden-Baden: Nomos-Verlagsgesellschaft.

Blankart, C.B. (2008). Öffentliche Finanzen in der Demokratie. München: Vahlen.

Boix, C. (1997). Political parties and the supply side of the economy: The provision of physical and human capital in advanced economies, 1960-90. American Journal of Political Science 41, 814-845.

Busemeyer, M.R. (2007). Determinants of public education spending in 21 OECD democracies, 1980-2001. Journal of European Public Policy 14, 582-610.

Busemeyer, M.R. (2009). Social democrats and the new partisan politics of public investment in education. Journal of European Public Policy 16, 107-126.

Busemeyer, M.R., Cattaneo, M.A. \& Wolter, S.C. (2011). Individual policy preferences for vocational versus academic education.

Journal of European Social Policy 21, 153-173.

Dahlberg, M. \& Mörk, E. (2011). Is there an election cycle in public employment? Seperating time effects from election year effects. CESifo Economic Studies 57, 480-498.

De Haan, J. \& Zelhorst, D. (1993). Positive theories of public debt: Some evidence for Germany. In: Verbon, H.A.A. \& van Winden, F.A.A.M. (eds.). The political economy of government debt. Amsterdam: Elsevier Science Publishers B. V., 295-306. 
Dietrich, H. \& Gerner, H.-D. (2012). The effects of tuition fees on the decision for higher education: evidence from a German policy experiment. Economics Bulletin 32, 24072413.

Downs, A. (1957). An Economic Theory of Democracy. New York: Harper and Row Publishers.

Dwenger, N., Storck, J. \& Wrohlich, K. (2012). Do tuition fees affect the mobility of university applicants? Evidence from a natural experiment.

Economics of Education Review 31, 155-167.

Ebcinoglu, F. (2006). Die Einführung allgemeiner Studiengebühren in Deutschland. Hochschul-Informations-System, Kurzinformation A 4/2006.

Elinder, M. \& Jordahl, H. (2013). Political preferences and public sector outsourcing, European Journal of Political Economy 30, 43-57.

Fisher, D., Rubenson, K., Jones, G. \& Shanahan, T. (2009). The political economy of postsecondary education: a comparison of British Columbia, Ontario and Québec. Higher Education 57, 549-566.

Freier, R. \& Odendahl, C. (2012). Do parties matter? Estimating the effect of political power in multi-party systems. DIW Discussion Papers 1205, Berlin.

Hassan, G. \& Warhurst, C. (2001). New Scotland? Policy, parties and institutions. The Political Quarterly 72, 213-226.

Hillman, A.L. (2009). Public Finance and Public Policy: Responsibilities and Limitations of Government. $2^{\text {nd }}$ edition. Cambridge University Press.

Hoffmann, N. (2011). Die Neuordnung der Studienfinanzierung in Großbritannien. Ifo Schnelldienst 9, 60-63.

Huber, P.J. (1967). The behavior of maximum likelihood estimates under nonstandard conditions. Proceedings of the Fifth Berkeley Symposium on Mathematical Statistics and Probability, 221-233.

Hübner, M. (2012). Do tuition fees affect enrollment behavior? Evidence from a 'natural experiment' in Germany. Economics of Education Review 31, 949-960.

Iversen, T. \& Stephens, J.D. (2008). Partisan politics, the welfare state, and three worlds of human capital formation. Comparative Political Studies 41, 600-637.

Jensen, C. (2011). Capitalist systems, de-industrialization, and the politics of public education. Comparative Political Studies 44, 412-435. 
Kemnitz, A. (2007). University funding reform, competition, and teaching quality. Journal of Institutional and Theoretical Economics 163, 356-378.

Kemnitz, A. (2010). Educational federalism and the quality effects of tuition fees. CESifo Working Paper No. 3193, Munich.

Krause, N. (2008). Die Debatte um Studiengebühren: Systematische Rekonstruktion eines rapiden Meinungswandels. Wiesbaden: VS Verlag für Sozialwissenschaften.

Liang, C.-Y. (2013). Is there an incumbency advantage or cost of ruling in proportional election systems? Public Choice 154, 259-284.

Merzyn, W. \& Ursprung, H.W. (2005). Voter support for privatizing education: evidence on self-interest and ideology. European Journal of Political Economy 25, 33-58.

Neill, C. (2009). Tuition fees and the demand for university places. Economics of Education Review 28, 561-570.

Oberndorfer, U. \& Steiner, V. (2007). Generationen- oder Parteienkonflikt? Eine empirische Analyse der deutschen Hochschulausgaben.

Perspektiven der Wirtschaftspolitik 8, 165-183.

Potrafke, N. (2011a). Public expenditures on education and cultural affairs in the West German states: does government ideology influence the budget composition? German Economic Review 12, 124-145.

Potrafke, N. (2011b). Does government ideology influence budget composition? Empirical evidence from OECD countries. Economics of Governance 12, 101-134.

Potrafke, N. (2012). Is German domestic social policy politically controversial? Public Choice 153, 393-418.

Potrafke, N. (2013). Economic freedom and government ideology across the German states. Regional Studies 47, 433-449.

Poutvaara, P. (2004). Educating Europe: should public education be financed with graduate taxes or income-contingent loans? CESifo Economic Studies 50, 663-684.

Poutvaara, P. (2011). The expansion of higher education and time-consistent taxation. European Journal of Political Economy 27, 257-267.

Poutvaara, P. \& Kanniainen, V. (2000). Why invest in your neighbor? Social contract on educational investment. International Tax and Public Finance 7, 547-562.

Schindler, D. (2011). Tuition fees and the dual income tax: the optimality of the Nordic income tax system reconsidered. German Economic Review 12, 59-84. 
Schmidt, M.G. (2007). Testing the retrenchment hypothesis: education spending, 1960-2002. In: Castles, F.G. (eds.). The disappearing state? Retrenchment realities in an age of globalization. Celtenham: Edward Elgar, 159-183.

Schulze, G.G. (2008). Tertiary education in a federal system: the case of Germany. In: Albert, M., Schmidtchen, D. \& Voigt, S. (eds.). Scientific Competition. Tübingen: Mohr Siebeck, 35-66.

Stock, J. H. \& Watson, M.W. (2008). Heteroskedasticity-robust standard errors for fixed effects panel data regression, Econometrica 76, 155-174.

Tepe, M. \& Vanhuysse, P. (2009). Educational business cycles - The political economy of teacher hiring across German states, 1992-2004. Public Choice 139, 61-82.

Tepe, M. \& Vanhuysse, P. (2013). Cops for hire? The political economy of police employment in the German states. Journal of Public Policy, forthcoming.

Todosijevic, B. (2005). Issues and Party Preferences in Hungary: A Comparison of Directional and Proximity Models. Party Politics 11, 109-126.

Ursprung, H.W. (2003). Lobbying and political polarization. Rivista di Politica Economica 93, 19-48.

Welsh, H.A. (2004). Higher Education in Germany: reform in incremental steps. European Journal of Education 39, 359-375.

White, H. (1980). A Heteroskedasticity-consistent covariance matrix estimator and a direct test for heteroskedasticity. Econometrica 48, 817-838.

White, H. (1982). Maximum likelihood estimation of misspecified models. Econometrica 50, 1-25.

Wolf, F. (2007). Die Bildungsausgaben der Bundesländer: Bestimmungsfaktoren und sozialpolitische Relevanz. Zeitschrift für Sozialreform 53:1, 31-56. 


\section{Appendix - Sources of the party platforms}

(BB=Brandenburg, BE=Berlin, BW=Baden-Wuerttemberg, BY=Bavaria, HB=Bremen, HE=Hesse, HH=Hamburg, MV=MecklenburgWestern Pomerania, NI=Lower Saxony, NW=North Rhine-Westphalia, $\mathrm{RP}=$ Rhineland-Palatinate, $\mathrm{SH}=\mathrm{Schleswig}-\mathrm{Holstein}, \mathrm{SL}=\mathrm{Saarland}$, $\mathrm{SN}=$ Saxony, $\mathrm{ST}=$ Saxony-Anhalt, $\mathrm{TH}=$ Thuringia)

B'90/Grüne (BB). Programm für die Landtagswahlen 2009. http://gruene-

brandenburg.de/userspace/BB/lv_brandenburg/landtagswahlprogramm/276576.buendnisgruen es_landtagswahlprogramm_200.pdf

B'90/Grüne (BE). Das Wahlprogramm zur Berliner Abgeordnetenhauswahl 2011. http:/gruene-berlin.de/sites/default/files/gemeinsam/Wahl2011/wahlprogramm_online.pdf

B'90/Grüne (BW). Das neue Programm für Baden-Württemberg 2011. http://www.gruenebw.de/fileadmin/gruenebw/dateien/Wahlen2011/Landtagswahlprogramm-web.pdf

B'90/Grüne (BY). Unser Wahlprogramm 2008-2013.

http://www.abgeordnetenwatch.de/images/programme/gruene_wahlprogramm.pdf

B'90/Grüne (HB). Wahlprüfsteine Hochschulpolitik: Antworten von Bündnis 90/Die Grünen Bremen. Studis Online. http://www.studis-online.de/HoPo/art-1201-1tw-bremen2011gruene.php

B'90/Grüne (HE). Landtagswahlprogramm 2008. http://www.gruenehessen.de/partei/files/2010/05/landtagswahlprogramm_2008.pdf

B'90/Grüne (HH). Wahlprogramm für die Bürgerschaftswahl 2011.

http://hamburg.gruene.de/sites/hamburg.gruene.de/files/dokument/17-012011/landeswahlrogrammonline.pdf

B'90/Grüne (MV). Programm zur Landtagswahl 2006.

http://www.abgeordnetenwatch.de/images/programme/lwp_gruene_2006.pdf

B'90/Grüne (NI). Landtagswahlprogramm 2008 - 2013. http://www.grueneniedersachsen.de/cms/default/dokbin/207/207239.landtagswahlprogramm2008.pdf

B'90/Grüne (NW). Das Programm zur Landtagswahl 2010. http://www.gruenenrw.de/fileadmin/user_upload/gruenenrw/aktuelles/2010/1tw/programm/gruener_zukunftsplan.pdf

B'90/Grüne (RP). Programm zur Landtagswahl 2011. http://gruenerlp.de/userspace/RP/lv_rlp/pdfs/gruene_dokumente/Programm_LW_2011_net.pdf

B'90/Grüne (SH). Das Grüne Arbeitsprogramm für Schleswig-Holstein 2012.

http://www.sh.gruene.de/cms/default/dokbin/401/401759.1andtagswahlprogramm_buendnis90 die_gruen.pdf

B'90/Grüne (SL). Landtagswahlprogramm 2012. http://www.gruene-

surfer2.de/saarland2012/wp-content/uploads/2012/02/Wahlprogramm_2012.pdf 
B'90/Grüne (SN). Sanieren statt Gebühren. Bündnis 90/Die Grünen Sachsen.

http://www.gruene-sachsen.de/aktuell/meldung/ansicht/125/sanieren-statt-gebuehren.html

B'90/Grüne (ST). Landtagswahlprogramm 2011. http://www.sachsen-anhalt.gruenepartei.de/cms/default/dokbin/349/349209.zukunftsprogramm.pdf

B'90/Grüne (TH). Landtagswahlprogramm 2009.

http://www.abgeordnetenwatch.de/images/programme/gruene thueringen.pdf

CDU (BB). Wahlprogramm der CDU Brandenburg zur Landtagswahl am 27. September 2009.

http://www.abgeordnetenwatch.de/images/programme/cdu_brandenburg_programm.pdf

CDU (BE). Wahlprogramm zu den Berlin-Wahlen am 17. September 2006.

http://www.cduberlin.de/attachments/article/161/Diskussionspapier_Wahlprogramm.pdf

CDU (BW). Regierungsprogramm der CDU Baden-Württemberg 2006 - 2011.

http://www.cdu-bw.de/uploads/media/CDU_RegierungsProgramm_web_02.pdf

CSU (BY). CSU-Mehrheit lehnt Abschaffung der Studiengebühren ab. Bayerischer Landtag. http://www.bayern.landtag.de/cps/rde/xchg/landtag/X/-/www1/17_3154.htm

CDU (HB). Wahlprogramm der CDU Bremen. http://www.cdubremen.de/userfiles/file/CDU Wahlprogramm 2011.pdf

CDU (HE). Corts: „Fair, finanzierbar und sozial ausgewogen“. FAZ Rhein-Main.

http://www.faz.net/aktuell/rhein-main/region/studiengebuehren-corts-fair-finanzierbar-undsozial-ausgewogen-1327530.html

CDU (HE). Das Wahlprogramm der CDU Hessen für den Wahlkampf 2009.

http://www.claudia-ravensburg.de/service/ltw_programm2009.pdf

CDU (HH). Wahlen zur Bürgerschaft in Hamburg: Was die CDU will. Studis Online. http://www.studis-online.de/HoPo/art-728-ltw-hamburg2008-cdu.php

CDU (MV). Wahlprogramm der CDU Mecklenburg-Vorpommern 2011. http://www.cdumecklenburg-vorpommern.de/fileadmin/redakteure/PDFs/Wahlprogramm_2011.pdf

CDU (NI). Regierungsprogramm 2008 - 2013 der CDU in Niedersachsen.

http://www.abgeordnetenwatch.de/images/programme/cdu_nds.pdf

CDU (NW). Beschluss des 31. Landesparteitags der CDU Nordrhein-Westfalen. Neue

Sicherheit und Solidarität Nordrhein-Westfalen 2020. http://www.cdu-

nrw.de/images/stories/docs/ltw2010/neue sicherheit und solidaritaet-nrw 2020.pdf

CDU (RP). Das Zukunftsprogramm 2011.

http://neu.cdurlp.de/fileadmin/Landtagswahl_2011/Flugblatt/ZukunftsProgramm2011.pdf

CDU (SH). Das Regierungsprogramm 2012-2017 für Schleswig-Holstein. http://www.cdush.de/content/download/154487/1810216/version/1/file/Regierungsprogramm+der+CDU+201 2-2017.pdf 
CDU (SL). CDU- Fraktionsvorsitzender Jürgen Schreier zu Studiengebühren im Saarland. CDU Fraktion im Landtag des Saarlandes. http://www.cdu-fraktionsaar.de/content/themen/34847.htm

CDU (SL). Wahlprüfsteine Hochschulpolitik: Antworten der CDU Saar. Studis Online. http://www.studis-online.de/HoPo/art-1365-ltw-saar2012-cdu.php

CDU (SN). Regierungsprogramm 2009-2014 der Sächsischen Union. http://wissen.cdusachsen.de/images/stories/dokumente/Regierungsprogramm_2009-2014.pdf

CDU (ST). Regierungsprogramm der CDU Sachsen-Anhalt 2011-2016. http://cdulsa.eckpunkt.de/ftp/PDF/Regierungsprogramm2011-2016.pdf

CDU (TH). Entwurf des Regierungsprogramms 2009 - 2014.

http://www.cdu.de/doc/pdfc/090203-regierungsprogramm-cdu-thueringen.pdf

DIE LINKE. (BB). Wahlprogramm der LINKEN Brandenburg zur Landtagswahl 2009. http://www.dielinke-

brandenburg.de/fileadmin/1._LPT/4.Tagung/PDF/Wahlprogramm_DIELINKE_BB.pdf

DIE LINKE. (BE). Wahlprogramm der LINKEN Berlin zur Landtagswahl 2009.

http:/www.tagesspiegel.de/downloads/3949162/3/pdf:\%20Wahlprogramm\%20der\%20Links partei

DIE LINKE. (BW). Wahlprogramm der LINKEN Baden-Württemberg zur Landtagswahl 2009. http://www.die-linke-bw.de/fileadmin/lv/landesdokumente/ltw11/ltw11wahlprogramm-linke.pdf

DIE LINKE. (BY). Wahlprogramm der LINKEN Bayern zur Landtagswahl 2009. http://www.die-linkebayern.de/fileadmin/Landtagswahlkampf/Material/Wahlprogramm_download.pdf

DIE LINKE. (HB). Wahlprogramm der LINKEN Bremen zur Landtagswahl 2009. http://www.dielinkebremen.de/fileadmin/user_upload/Wahlen_2011/LinkeBRE_Langwahlprogramm_Neu.pdf

DIE LINKE. (HE). Programm zur Landtagswahl am 27. Januar 2008. http://www.die-linkehessen.de/cms/content/view/6/7/

DIE LINKE. (HH). Wahlprogramm Bürgerschaftswahl 2011. http://fuer-ein-sozialeshamburg.de/fileadmin/fuer-ein-sozialeshamburg.de/DIE_LINKE_Wahlprogramm_Hamburg_2011.pdf

DIE LINKE. (MV). Wahlprogramm zu den Landtagswahlen 2011.

http://www.abgeordnetenwatch.de/images/programme/original_wahlprogramm_linke_mv.pdf

DIE LINKE. (NI). Programm der Fraktion DIE LINKE im niedersächsischen Landtag 2008 2013. http://www.kreszentia-

flauger.de/media/LTW08_Landeswahlprogramm_DIE_LINKE_NDS_.pdf 
DIE LINKE. (NW). Wahlprogramm DIE LINKE. NRW - Landtagswahl 2010.

http://www.dielinke-nrw.de/fileadmin/kundendaten/www.dielinke-

nrw.de/LTW/DIE_LINKE.NRW_Langwahlprogramm.pdf

DIE LINKE. (RP). Landtagswahlprogramm DIE LINKE Rheinland-Pfalz.

http://www.abgeordnetenwatch.de/images/programme/die_linke_wahlprogramm_2011_rlp.pd f

DIE LINKE. (SH). Wahlprogramm zur Landtagswahl 2012. http://www.wvhsh.de/uploads/media/Linke_Wahlprogramm.pdf

DIE LINKE. (SL). Programm zur Landtagswahl 2009. http://www.dielinkesaar.de/fileadmin/Pdf-Dateien/Dokumente/Wahlbroschuere_Internet.pdf

DIE LINKE. (SN). Landeswahlprogramm 2009.

http://www.abgeordnetenwatch.de/images/programme/linke_sachsen.pdf

DIE LINKE. (ST). Wahlprogramm für die Landtagswahl in Sachsen-Anhalt am 20. März 2011. http://www.dielinke-sachsen-

anhalt.de/fileadmin/Matthias_Hoehn/Dokumente/Wahlprogramm_LTW2011_DIELINKE.pdf

DIE LINKE. (TH). Das Regierungsprogramm der LINKEN zur Landtagswahl 2009.

http://www.abgeordnetenwatch.de/images/programme/die_linke_thueringen.pdf

FDP (BB). Brandenburg 2009 bis 2014: Ein Wahlprogramm.

http://www.abgeordnetenwatch.de/images/programme/fdp_brandenburg_programm.pdf

FDP (BE). Wahlprogramm der FDP Berlin 2011.

http://www.tagesspiegel.de/downloads/3953214/4/PDF:\%20Wahlprogramm\%20der\%20Berli ner $\% 20$ FDP

FDP (BW). Regierungsprogramm 2011 - 2016. http://www.fdp-

bw.de/docs/ltw2011_programm_web.pdf

FDP (BY). Liberales Programm zur Landtagswahl 2008. http://www.fdp-

bayern.de/files/86/FDP-Wahlprogramm08.pdf

FDP (HB). Bürgerprogramm 2011.

http:/www.abgeordnetenwatch.de/images/programme/fdp_wahlprogramm_2011.pdf

FDP (HE). Programm zur Landtagswahl 2008.

http://www.abgeordnetenwatch.de/images/programme/fdp_hessen08.pdf

FDP (HH). Wahlprogramm der FDP Hamburg 2011.

http://www.nachhaltigkeit.info/media/1298375858phpGha8gU.pdf

FDP (MV). Liberales Programm zur Landtagswahl 2011 in Mecklenburg-Vorpommern.

http://www.abgeordnetenwatch.de/images/programme/original_wahlprogramm_fdp_mv.pdf

FDP (NI). FDP Programm zur Landtagswahl 2008.

http://www.abgeordnetenwatch.de/images/programme/fdp_nds.pdf 
FDP (NW). Das Programm zur nordrhein-westfälischen Landtagswahl 2010. http://www.fdpnrw.de/files/557/100325_Wahlgrogramm_Finalversion.pdf

FDP (RP). Programm der FDP Rheinland-Pfalz zur Landtagswahl 2011. http://www.fdp-rpkreis.de/pdf/2011/FDP-LTW-Programm_2011.pdf

FDP (SH). Landtagswahlprogramm 2012 - 2017 der FDP Schleswig-Holstein.

http://www.fdp-norderstedt.de/tl_files/fdp-norderstedt/downloads/Wahlprogramm_20122017.pdf

FDP (SL). Programm zur Landtagswahl am 25. März 2012. http://www.fdp-saar.de/wpcontent/uploads/2012/02/wahlprogramm2012.pdf

FDP (SN). Landtagswahlprogramm der FDP Sachsen 2009. http://www.fdpsachsen.de/online/fdp/cisweb3_Media_FDP.nsf/(File)/EC069A242267B0B0C12575CB0048 E9A1/\$File/Wahlprogramm\%20FDP\%20Sachsen\%20LTW\%202009\%20final.pdf

FDP (ST). Wahlprüfsteine Hochschulpolitik: Antworten der FDP Sachsen-Anhalt. Studis Online. http://www.studis-online.de/HoPo/art-1176-1tw-sachsen-anh2011-fdp.php

FDP (TH). Wahlprogramm der FDP Thüringen für die Landtagswahl am 30. August 2009. http://www.abgeordnetenwatch.de/images/programme/fdp_thueringen.pdf

SPD (BB). Regierungsprogramm der SPD Brandenburg zur Landtagswahl am 27. September 2009. http://www.abgeordnetenwatch.de/images/programme/spd_brandenburg_programm.pdf

SPD (BE). BERLINprogramm 2011-2016. http://www.spd-berlin.de/w/files/spdparteitage/spd_berlinprogramm_2011_2016web.pdf

SPD (BW). Regierungsprogramm der SPD Baden-Württemberg 2011-2016. http://www.warumspd.de/regierungsprogramm.pdf

SPD (BY). Regierungsprogramm der BayernSPD 2008-2013. http://www.spd-muenchenau.de/uploads/programme/BayernSPD_Regierungsprogramm_08-13.pdf

SPD (HB). Regierungsprogramm 2012 - 2017. http://www.spd-landbremen.de/uploads/media/Regierungsprogramm_2011-2015_09.pdf

SPD (HE). Sozialdemokratisches Regierungsprogramm 2008 - 2013. http://www.spdhessen.de/db/docs/doc_16621_2007117151725.pdf

SPD (HH). SPD-Regierungsprogramm für Hamburg 2011. http://www.spdhamburg.de/cms/fileadmin/LO/Dokumente/Parteitage/150111/SPD_Regierungsprogramm_20 11.pdf

SPD (MV). Regierungsprogramm 2011 - 2016.

http://www.abgeordnetenwatch.de/images/programme/original_wahlprogramm_spd_mv.pdf 
SPD (NI). Regierungsprogramm der SPD Niedersachsen 2008-2013.

http:/www.spdnds.de/imperia/md/content/landesverbandniedersachsen/ltw2008/regierungspr ogrammweb.pdf

SPD (NW). Programm zur Landtagswahl am 9. Mai 2010.

http://nrwspd.de/db/docs/doc_28254_201032415641.pdf

SPD (RP). Regierungsprogramm $2011-2016$.

http://spdnet.sozi.info/rlp/dl/Regierungsprogramm_Endversion.pdf

SPD (SH). Regierungsprogramm 2012 - 2017. http://spd.sh/g605c

SPD (SL). Beschlussbuch, Landesparteitag, SPD Saar, 2007. http://www.spdsaar.de/uploads/media/Beschlussbuch_LPT07.pdf

SPD (SN). Regierungsprogramm 2009-2014.

http://www.abgeordnetenwatch.de/images/programme/spd_sachsen.pdf

SPD (ST). Programm der SPD Sachsen-Anhalt zu den Landtagswahlen am 20. März 2011. http:/www.spd-sachsen-anhalt.de/files/wahl2011/wahlprogramm2011.pdf

SPD (TH). Regierungsprogramm der SPD Thüringen 2009-2014.

http://spdnet.sozi.info/thueringen/dl/SPD_Thueringen_Regierungsprogramm_2009-20141.pdf 